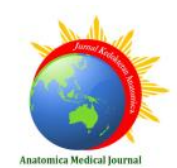

E-ISSN: 2614-5219

ARTIKEL PENELITIAN

\section{Perbedaan Kualitas Hidup dan Antropometri Bayi Usia 6-12 Bulan Berdasarkan MPASI di Puskesmas Dolok Masihul Kabupaten Serdang Bedagai Tahun 2019}

\author{
Melva Simatupang, Dewi Meliasari \\ Jurusan Kebidanan Poltekkes Kemenkes Medan \\ Email: meliasari0105@gmail.com
}

\begin{abstract}
Abstrak: Salah satu proses penting dalam pemenuhan gizi balita adalah pemberian Air Susu Ibu (ASI) dan Makanan Pendamping ASI (MPASI). Pemberian MPASI selain dapat meningkatkan berat badan, mencegah kejadian gizi buruk, dapat juga menilai kualitas hidup bayi dengan pertimbangan kualitas hidup seseorang dinilai dari tahun pertama kehidupannya. Penilaian kualitas hidup bayi dalam penelitian ini menggunakan kuesioner SF (Short Form)-36 yang telah baku (Rand,2009). Penelitian menggunakan teknik Survei Analitik dengan Rancangan Cross Sectional. Sampel adalah bayi usia 6-12 bulan di Wilayah Kerja Puskesmas Dolok Masihul yaitu pengambilan sampel teknik probability sampling. Hasil penelitian diketahui bahwa dari uji Tindependen didapat variabel kualitas hidup dengan $p=0,041<0,05$, ada perbedaan kualitas hidup bayi berdasarkan MPASI. Sedangkan variabel antropometri diperoleh $p=0,026<0,05$ sehingga ada juga perbedaan antropometri berdasarkan jenis pemberian MPASI. Hasil uji Multivariat dengan Uji Manova, hotelling's trace menunjukan signifikan $(p=0,037)$ di bawah 0,05 berarti ada perbedaan secara bersamaan kualitas hidup dan antropometri pada berbagai jenis pemberian MPASI. Diharapkan masyarakat lebih memanfaatkan setiap peluang untuk berperan aktif dalam meningkatkan dan memahami pentingnya pemberian makanan pendamping. Kepada para petugas kesehatan (bidan) dapat terus memberikan informasi berkaitan dengan cara pemberian MPASI yang baik.
\end{abstract}

Kata kunci : MPASI, kualitas hidup, antropometri

\section{Differences in Quality of Life and Anthropometry of Infants Aged 6-12 Months Based on MPASI at Dolok Masihul Puskesmas Serdang Bedagai District In 2019}

\begin{abstract}
One of the important processes in fulfilling the nutrition of children under five is giving breast milk (ASI) and complementary foods with breast milk (MPASI). In addition to increasing body weight, preventing the incidence of malnutrition, complementary feeding can also assess the quality of life of a baby by considering a person's quality of life from the first year of life. Assessment of the quality of life of infants in this study used a standardized SF (Short Form) -36 questionnaire (Rand, 2009). The study used Analytical Survey techniques with a Cross Sectional Design. The sample was babies aged 6-12 months in the Dolok Masihul Puskesmas working area, namely probability sampling technique. The results showed that from the independent T-test, the quality of life variable was obtained with $p=0.041<0.05$, there was a difference in the quality of life for babies based on MPASI. While the anthropometric variable obtained $p=0.026<0.05$ so that there are also anthropometric differences based on the type of complementary feeding.
\end{abstract}




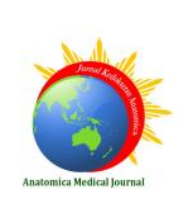

E-ISSN: 2614-5219

The results of the multivariate test with the Manova test, hotelling's trace showed a significant ( $p$ $=0.037$ ) below 0.05 which means that there is a simultaneous difference in quality of life and anthropometry on various types of complementary feeding. It is hoped that the community will take more advantage of every opportunity to play an active role in improving and understanding the importance of complementary feeding. To health workers (midwives) can continue to provide information related to good complementary feeding practices.

Keywords: MPASI, quality of life, anthropometry.

\section{PENDAHULUAN}

Target Millenium Development Goals (MDGs) 2015 terhadap Angka Kematian Bayi (AKB) sebesar 23 per 1.000 kelahiran hidup. Hasil SUPAS 2015 diketahui AKB sebesar 22,23 per 1.000 kelahiran hidup yang berarti sudah dibawah target MDGs ${ }^{1}$. Namun berdasarkan hasil riset Badan Pusat Statistik (BPS), AKB di Indonesia masih tinggi jika dibandingkan dengan Negara tetangga seperti Malaysia, juga Singapura yang sudah dibawah 10 kematian per 1.000 kelahiran bayi.

Berdasarkan laporan dari WHO dan UNICEF diketahui bahwa factor utama kematian anak, adalah gizi, penyakit dan kecacatan, Faktor yang berhubungan dengan gizi berkontribusi sekitar $45 \%$ dari kematian balita, diantaranya berat badan lahir rendah, kurang gizi, anak yang tidak diberi ASI dan lingkungan yang tidak sehat. Anak kurang gizi memiliki resiko kematian lebih tinggi akibat penyakit infeksi penyakit, seperti diare, pneumonia dan campak ${ }^{\mathbf{1 , 2}}$.

Pengukuran Status gizi balita menggunakan indeks antropometri, terdiri dari : berat badan / umur (BB/U), tinggi badan / umur (TB/U) dan berat badan / tinggi badan (BB/TB). Pengukuran yang menggunakan indeks antropometri berdasarkan Standar WHO (2005) dan keputusan Menteri KesehatanNo.1995/Menkes/SK/XII/2010². Prevalensi gizi buruk dan kurang pada balita di Sumatera Utara, tahun 2016 sebesar (13.3\%), meningkat pada Tahun 2017 sebesar $18.2 \%$. Berdasarkan data tersebut maka prevalensi gizi buruk dan kurang di Sumatera Utara termasuk dalam kategori medium (5-9\% rendah, 10-19\% medium, 20$39 \%$ tinggi, $>40 \%$ sangat tinggi, standar WHO) $)^{3}$.

Gambaran status gizi balita sesuait indeks $\mathrm{BB} / \mathrm{U}$ di tiap kabupaten/kota provinsi Sumatera Utara tahun 2017, Babupaten Serdang Bedagai angka gizi buruk sebesar $9.3 \%$, gizi kurang $17.4 \%$, dalam hal ini menduduki posisi ke-8 di Sumatera Utara (Dinkes Sumut, 2018). Sementara itu daerah Dolok Masihul sebagai salah satu kecamatan yang ada di Serdang Bedagai, persentase gizi buruknya sebesar $0.71 \%$, gizi kurang $1.18 \%{ }^{4}$.

Satu bagian penting dalam pemenuhan gizi balita adalah dengan pemberian Air Susu Ibu 
(ASI) dan juga pemberian makanan pendamping ASI (MPASI). ASI merupakan sumber makanan yang paling penting untuk bayi karena mengandung elemen gizi yang diperlukan dalam pertumbuhan dan perkembangan. ketika bayi berumur kurang dari 6 bulan cukup hanya ASI saja (ASI Eksklusif). Setelah bayi berusia 6 bulan, ia harus mulai diperkenalkan dengan makanan padat yang disebut MPASI ${ }^{5.6 .7}$.

Seperti yang telah diketahui, MPASI terdiri dari MPASI Instan (buatan pabrik) dan MPASI Alami (buatan rumah) ${ }^{7}$. Berdasarkan penelitian Olivia (2016) di desa Mopusi kecamatan Lolayan kabupaten Bolaang Mongondow Induk ternyata MPASI alami (buatan rumah) lebih banyak dikonsumsi oleh bayi daripada MPASI instan (buatan pabrik) karena ibu berpikir MPASI alami lebih bagus daripada MPASI instan.

Faktanya, berdasarkan kandungan gizi lebih banyak gizi MPASI instan (buatan pabrik) dibandingkan MPASI alami. Sebenarnya didalam buku KIA cara pembuatan MPASI alami termsuk materi yg utama. Tetapi karena melihat kepraktisan dalam penyajiannya, maka MPASI instan lebih banyak disukai. MPASI buatan pabrik dibuat berdasarkan ketentuan khusus (Codex Alimentaris) dari WHO yang meliputi standar keamanan, higienitas dan kandungan nutrisi. MPASI buatan pabrik juga memiliki kandungan gizi yang sesuai kebutuhan nutrisi bayi. Selain gizi yang terukur dan keamanan yang baik, MPASI buatan pabrik juga menghemat waktu, ibu dapat memilih jenis dan rasa MPASI yang disukai oleh bayi 7.8 .9 .

Pemberian MPASI baik secara alami ataupun instan selain dapat meningkatkan berat badan untuk mencegah kejadian gizi buruk, dapat juga dinilai kualitas hidup bayi dengan pertimbangan bahwa kualitas hidup seseorang dinilai dari tahun pertama kehidupannya. Penilaian kualitas hidup bayi dalam penelitian ini menggunakan kuesioner SF (Short Form)-36 yang telah baku ${ }^{10.11 .12}$. Dimensi penilaian SF-36 ada delapan dimensi, tetapi dalam penelitian ini yang dinilai hanya tuga dimensi yaitu dimensi fungsi fisik, peranan fisik dan kesehatan secara umum. Sejauh ini penulis belum mengetahui penilaian kualitas hidup bayi menggunakan kuesioner $S F-36$, oleh karena itu dalam penelitian ini penulis ingin mencoba menilai kualitas hidup bayi menggunakan modifikasi kuesioner SF-36. Sepengetahuan penulis $S F-36$ telah banyak digunakan untuk penilaian kualitas hidup orang yang terkait dengan penyakit tertentu, seperti hipertensi, stroke, TB Paru dll.

Berdasarkan survey pendahuluan yang dilakukan oleh penulis dengan melihat data puskesmas tahun 2018, dari bulan Desember 
2018 - Januari 2019 di Puskesmas Kecamatan Dolok Masihul Kabupaten Serdang Bedagai terdapat 425 bayi yang berusia 6-12 bulan. Salah satu desa wilayah kerja puskesmas tersebut adalah Desa Dolok Manampang terdapat 40 bayi yang berusia 612 bulan (hasil pengamatan penulis).

Beberapa fakta yang penulis temukan dari lapangan atau desa tersebut bahwa umumnya ibu masih memberikan MPASI hanya berupa bubur nasi (tim) saja dan pemberian MPASI masih menggunakan susu formula 6-12 bulan dan biskuit. Oleh karena itu, penulis tertarik untuk meneliti jenis pemberian MPASI oleh ibu di Desa Dolok Masihul Serdang Bedagai.

\section{METODE PENELITIAN}

Jenis penelitian yang dilakukan adalah penelitian Survei Analitik dengan Rancangan Cross Sectional. Tujuan penelitian ingin mengetahui Perbedaan Kualitas Hidup dan Antropometri Pada Bayi diatas Usia 6 bulan.

\section{Populasi \& sampel}

Populasi penelitian i adalah bayi dengan usia 6 bulan sampai satu tahun sebanyak 425 . Kriteria inklusi: a) Ibu sukarela jadi subjek penelitian

b) Usia bayi 6-12 bulan yang berdomisili sekitar wilayah Puskesmas Dolok Masihul

c) Bayi yang diberi MPASI oleh ibu

d) Bayi tidak diberikan susu formula Kriteria eksklusi:

a) Bayi yang tidak diberi MPASI oleh ibu

b) Bayi dengan penyakit penyerta lainnya, seperti: Gizi Kurang /Buruk, Diare, TB, Kelainan Kongenital dll.

Pengumpulan data dilakukan dengan dibantu tenaga kader kesehatan dan bidan di puskesmas, juga beberapa orang enumerator yang sengaja dibawa peneliti, pengambilan data dilakukan pada saat pelaksanaan posyandu di Desa Kerapuh pada tiga lokasi Posyandu, yaitu Posyandu Melati I, Posyandu Melati II dan Posyandu Melati III Analisa

Analisis Bivariat digunakan untuk mengetahui perbedaan rata rata berat badan berdasarkan jenis MPASI, digunakan Uji T Independen. Analisa multivariat, digunakan analisa Uji Manova dengan batas kemaknaan 0,05 . 


\section{HASIL PENELITIAN}

Tabel 4.3 Deskriptif Kualitas Hidup dan Antropometri di Wilayah Kerja Puskesmas

\begin{tabular}{cccccc}
\hline Variabel & n & Minimum & Maksimum & Mean & SD \\
\hline $\begin{array}{c}\text { Kualitas } \\
\text { hidup }\end{array}$ & 81 & 29 & 51 & 39,30 & 5,430 \\
\hline Antropometri & 81 & 0,5 & 2,2 & 1,511 & 0,526 \\
\hline
\end{tabular}

Pada Tabel 4.3 dapat dibaca nilai rata-rata kualitas hidup adalah skor 39,30 dan nilai SD skor 5,430 dengan nilai minimum skor 29 dan maksimum skor 51. Nilai rata-rata antropometri adalah skor 1,511 dan nilai SD 0,526 dengan nilai minimum skor 0,5 dan maksimum skor 2,2.

Tabel 4.4 Hasil Uji Perbedaan Rata-Rata Kualitas Hidup dan Antropometri Berdasarkan Jenis Pemberian MPASI

\begin{tabular}{lccccccc}
\hline \multicolumn{1}{c}{ Variabel } & Jenis MPASI & N & \multirow{2}{*}{ Mean } & SD & \multirow{2}{*}{} & \multicolumn{2}{c}{ 95\%CI } \\
\hline Kualitas & & & & & & Lower & Upper \\
Hidup & Instan & 40 & 38,05 & 5,198 & & & \\
\multirow{3}{*}{ Antropometri } & Alami & 41 & 40,51 & 5,437 & & & \\
& Instan & 40 & 1,380 & 0,534 & & & \\
& Alami & 41 & 1,639 & 0,491 & 0,026 & $-0,486$ & $-0,032$ \\
\hline
\end{tabular}

Pada tabel 4.4 terlihat hasil uji T-independen didapat nilai $\mathrm{p}=0,041<0,05$ sehingga ada perbedaan kualitas hidup berdasarkan jenis pemberian MPASI. Rata-rata kualitas hidup dengan jenis pemberian MPASI alami sebesar 40,51 lebih tinggi dibanding kualitas hidup dengan jenis pemberian MPASI instan sebesar 38,05.

Setelah melalui uji Normalitas data ternyata data dinyatakan normal dan memenuhi syarat untuk uji selanjutnya dengan Uji Manova karena dapat memenuhi Uji Asumsi Homogenitas dengan Box's M dan Uji Levene Test.

Tabel 4.8 Perbedaan Rata-Rata Kualitas Hidup dan Antropometri Berdasarkan Jenis Pemberian MPASI menngunakan Uji Manova

\begin{tabular}{lllllcl}
\hline Effect & & Value & F & $\begin{array}{c}\text { Hypothesis } \\
\text { Df }\end{array}$ & $\begin{array}{c}\text { Error } \\
\text { df }\end{array}$ & Sig. \\
\hline Intercept & Hotelling's & 55,96 & 2,183 & 2,000 & 78,000 & 0,0001 \\
& Trace & 4 & & & & \\
\hline Jenis & Hotelling's & 0,088 & 3,448 & 2,000 & 78,000 & 0,037 \\
Pemberi & Trace & & & & & \\
an & & & & & & \\
MPASI & & & & & & \\
\hline
\end{tabular}


Pada tabel 4.8 terlihat pada baris jenis pemberian MPASI nilai signifikan yang diuji dengan hotelling's trace menunjukan angka signifikan $(0,037)$ di bawah 0,05 hal itu menunjukan bahwa secara bersamaan kualitas hidup dan antropometri menunjukan adanya perbedaan yang nyata pada berbagai jenis pemberian MPASI instan dengan alami.

\section{PEMBAHASAN}

\section{Karakteristik Bayi Usia 6-12 Bulan di} Wilayah Kerja Puskesmas Dolok Masihul Tahun 2019

$$
\text { Hasil menunjukkan bahwa }
$$

karakteristik bayi berdasarkan usia mayoritas berusia 7 bulan sebanyak 18 orang $(22,2 \%)$, berdasar JK mayoritas perempuan sebanyak 45 orang $(55,6 \%)$, dan untuk frekuensi pemberian dalam sehari mayoritas $2 \mathrm{x}$ sebanyak 74 orang $(91,4 \%)$.

Usia 0-24 bulan adalah masa pertumbuhan dan perkembangan yang sangat pesat dapat dikatakan sebagai periode emas (golden periode) tetapi sekaligus periode kritis. Periode emas dapat diwujudkan jika pada masa ini mendapatkan asupan nutrisi yang sesuai untuk tumbuh kembang optimal. Nutrisi yang dibutuhkan oleh bayi pada periode pertama yaitu ASI karena ASI mengandung nilai gizi yang sangat baik dan dapat dicerna dengan mudah serta dapat membantu membangaun daya tahan tubuh untuk bayi. Setelah usia 6 bulan maka bayi perlu diberi tambahan nutrisi selain ASI, yaitu dengan pemberian makanan pendamping ASI (MPASI). ASI adalah pilihan yang tepat sebagai sumber makan pada bayi karena mengandung nutrisi lengkap yang dibutuhkan oleh tubuh.

Hal ini sejalan dengan penelitian Sarah $(2008)^{6}$, bahwa MPASI diberikan pada bayi diatas usia 6 bulan. Disamping MPASI, ASI juga tetap diberikan sampai berusia 24 bulan. Artinya MPASI bukan menggantikan ASI melainkan sebagai pelengkap ASI.

Almatsier dan Sunita (2009) ${ }^{13.14}$ mengatakan bahwa kebutuhan energi pada anak laki-laki lebih banyak dibandingkan kebutuhan anak perempuan sehingga anak laki-laki memiliki peluang lebih besar untuk menerima kebutuhan gizi dikarenakan aktivitas anak laki-laki lebih tinggi.

Gangguan pertumbuhan pada bayi biasanya terjadi setelah anak berusia 3 bulan, umumnya disebabkan beberapa faktor yaitu : 1) kurang terpenuhinya asupan energi dari air susu ibu (Asinya kurang) 2) rendahnya kandungan gizi dan nutrien dalam makanan tambahan yang diberikan (Negara berkembang); dan 3) dampak negative, adanya sumber infeksi pada asupan energy (hygiene) 
E-ISSN: 2614-5219

\section{Karakteristik Ibu Responden}

Hasil menunjukkan karakteristik ibu berdasarkan umur mayoritas berumur $\leq 35$ tahun sebanyak 58 orang $(71,6 \%)$, untuk anak ke mayoritas anak pertama sebanyak 31 orang $(38,3 \%)$, untuk pekerjaan ibu, mayoritas sebagai IRT sebanyak 69 orang $(85,2 \%)$, untuk pendidikan ibu mayoritas tingkat pendidikan adalah SMA/SMK sebanyak 53 orang $(65,4 \%)$, dan untuk penghasilan mayoritas <UMK sebanyak 44 orang $(54,3 \%)$.

Status pendidikan ibu sebagian besar tamat SMA/sederajat. Status pendidikan seseorang akan menentukan daya nalar ilmu atau pengetahuan yang diberikan. Biasanya semakin tinggi status pendidikan semakin baik daya nalar atau pengetahuan didapatkan.

Status pendidikan yang tinggi mempermudah seseorang dalam menyerap ilmu atau pengetahuan. Kesempatan mendapatkan pendidikan formal maupun informal diharapkan bisa meningkatkan dalam pengetahuan gizi keluarga pada Ibu. Pengetahuan sangat diperlukan oleh Ibu dalam upaya mengatur makanan dalam keluarga dan kesehatan adalah harapan tertinggi untuk keluarganya.

Penghasilan keluarga yang rendah mengakibatkan daya beli keluarga untuk makan rendah sehingga asupan gizi juga rendah, ketika asupan gizi rendah yang terus menerus bisa menyebabkan status gizi menurun, sehinga dapat mempengaruhi pertumbuhan dan perkembangan bayi dan balita.

Hubungan Kualitas Hidup dan Antropometri Bayi Berdasarkan Jenis pemberian MPASI di Wilayah Kerja Puskesmas Dolok Masihul Tahun 2019

Hasil menunjukkan kualitas hidup dan antropometri menunjukan adanya perbedaan pada berbagai jenis pemberian MPASI. Variabel kualitas hidup nilai $p=$ $0,041<0,05$ sehingga ada perbedaan kualitas hidup berdasarkan jenis MPASI. Rata-rata kualitas hidup dengan jenis pemberian MPASI alami sebesar 40,51 lebih tinggi dibanding kualitas hidup dengan jenis pemberian MPASI instan sebesar 38,05.

Variabel antropometri diperoleh nilai $p=0,026<0,05$ berarti ada perbedaan antropometri berdasarkan jenis pemberian MPASI. Rata-rata antropometri dengan jenis pemberian MPASI alami sebesar 1,639 lebih tinggi dibanding antropometri dengan jenis pemberian MPASI instan sebesar 1,380.

Berdasarkan hasil uji Manova bahwa jenis pemberian MPASI dengan hotelling's trace menunjukan nilai $p(0,037)<0,05$, menunjukan secara bersamaan baik kualitas hidup maupun antropometri menunjukan perbedaan yang nyata berdasarkan jenis 
E-ISSN: 2614-5219

MPASI.

Kebiasaan MPASI alami yang diberikan oleh ibu bisa disimpulkan lebih baik dibandingkan dengan MPASI instan. Hal ini dapat menunjukkan animo dan perhatian para ibu pada MPASI alami atau buatan sendiri cenderung menjadi habbit atau kebiasaan yang positif. Ditambah dengan aneka ragam menu yang dibaca didalam buku KIA, menjadikan point tambahan pengetahuan ibu yang sangat baik ${ }^{1.15 .16}$.

Pengetahuan dan pengalaman ibu tentang cara pemberian MPASI kepada bayi sebenarnya sudah mereka peroleh secara turun temurun, atau diajarkan oleh orangtuanya. Didukung dengan keadaan saat ini, kondisi sumber informasi demikian sudah sangat beragam dan lebih menarik, memberikan sarana tambahan kepada orangtua yang mempunyai bayi balita. Pemanfaatan media informasi memudahkan kepada para petugas kesehatan dalam melaksanakan tugasnya.

Kualitas hidup bayi yang ditunjukkan dengan perkembangan antropometri dengan pemberian MPASI alami ternyata memberikan dampak yang signifikan dibandingkan dengan pemberian MPASI Instan. Hal ini perlu dikembangkan dan dipertahankan karena MPASI alami cenderung lebih fresh dan tanpa ada bahan pengawet. Keanekaragaman bahan dan menu makanan yang tersedia dalam budaya kita juga bisa menjadikan satu kelebihan dan keistimewaan juga dalam MPASI alami ${ }^{17.8}$. Proses pembuatan makanan pendamping biasanya dilakukan sendiri oleh ibu karena umumnya ibu memang tidak bekerja. Jenis atau variasi makanan yang diberikan ibu sebagian besar sudah baik.

Pola pemberian makanan selingan sebagian besar sudah baik sesuai umur, bayi yang boleh diberikan makanan selingan adalah bayi dengan umur lebih dari 9 bulan dan diberikan 2 kali sehari bisa diberikan biskuit atau buah.

Sangat perlu untuk diingatkan kembali bahwa, pemberian ASI saja tidak cukup setelah bayi berusia 6 bulan, bayi harus mulai mendapatkan makanan pendamping ASI (MPASI) secara bertahap. MPASI harus memperhatikan beberapa hal, yaitu waktu pemberian (jadwal), berapa kali (frekuensi), berapa banyak diberikan (porsi), pemilihan jenis bahan makanan, bagaimana cara pembuatan dan bagaimana cara pemberiannya. Pemberian MPASI yang sesuai kandungan gizinya dan dapat diserap secara optimal akhirnya bisa mempengaruhi perkembangan otak, gerak motorik dan kualitas hidup bayinya ${ }^{18.21}$. 


\section{DAFTAR PUSTAKA}

1. Kemenkes RI. 2016. Profil Kesehatan Indonesia Tahun 2016. Jakarta: Departemen Kesehatan.

2. Kemenkes RI. 2017. Profil Kesehatan Indonesia Tahun 2017. Jakarta: Departemen Kesehatan.

3. Dinkes Sumut. 2018. Profil Kesehatan Provinsi Sumatera Utara Tahun 2018.

4. Puskesmas Dolok Masihul, Laporan Puskesmas Tahun 2018

5. Waryna. 2016. Gizi Reproduksi. Yogyakarta: Pustaka Rihama

6. Sarah, M. (2008). Hubungan Tingkat Sosial Ekonomi dan Pola Asuh dengan Status

Gizi Anak Balita di Wilayah Kerja Puskesmas Pantai Cermin Kecamatan Tanjung Pura Kabupaten Langkat Tahun 2008 (Skripsi, Universitas Sumatera Utara, Medan). Diakses dari http://repository. usu.ac.id/bitstream/123456789/16930/7/Cov er. Pdf

7. Sri R, Utami. 2018. Тор 300 Мепи Bayi \& Balita. Jakarta: PT Grasindo

8. Arum Utami, Fasty. 2018. MP-ASI Gizi Tepat. Yogyakarta: Oxygen Media Ilmu 9. Kemenkes. 2014. Pedoman Gizi Seimbang. Departemen Kesehatan RI. Jakarta

10. Vincenzo F, Giacomo N, Antonio G, Carlo S, and Roberto B, et al. 2005, Twelve- month self-reported quality of life afterretropublic radical prostatectomy : aprospective study with Rand 36-Item Health Survey (Short Form-36)

11. Fitri Ika Handayani, Skripsi, 2010, Perbedaan skor Kualitas Hidup Terkait Kesehatan Antara Pasien Stroke Iskemik serangan Pertama dan berulang

12. Ware, JE, Jr and Sherboourne, CD. 1992, The MOS 36-Item Short-Form Health Survey (SF-36) : I. Conceptual Framework and item selection: Medical Care, 30:473483

13. Almatsier \& Sunita. (2009). Prinsip dasar ilmu gizi. Jakarta: Gramedia

14. Fikawati, Sandra. 2017. Gizi Anak dan Remaja. Depok: PT Rajagrafindo Persada

15. Kemenkes RI. 2011. Standar Antropometri Penilaian Status Gizi Anak. Jakarta: Departemen Kesehatan.

16. Mardalena, Ida. 2017. Dasar-Dasar Ilmu Gizi dalam Keperawatan. Yogyakarta: Pustaka Baru Press

17. Istiany, A., Rusilanti. (2014). Gizi Terapan. Bandung: PT Remaja Rosdakarya 18. Kusmiyati, 2018. Nutrisi Di Awal Perkembangan, Program Studi Pendidikan Biologi FKIP Unram

19. Hanindita, Meta. 2018. Tanya-jawab tentang nutrisi di 1000 hari pertama 
Vol 3 No 3 September 2020

E-ISSN: 2614-5219

kehidupan anak. Jakarta: PT Gramedia Pustaka Utama

20. Winarsih. 2018. Pengantar Ilmu Gizi

Dalam Kebidanan. Yogyakarta: Pustaka Baru Press
21. Yuniarti, Sri. 2015. Status Gizi Anak Dunia.

http://www.who.int/gho/status_gizi_Anak_

Dunia/en. diakses pada tanggal 24 Mei 2019 